\title{
Corneal chrysiasis and clinical improvement with chrysotherapy in rheumatoid arthritis
}

\author{
P. J. PROUSE, J. J. KANSKI, AND J. M. GUMPEL
}

From Northwick Park Hospital, Harrow

SUMMARY The deposition of gold in the cornea-ocular chrysiasis-is a normal event during chrysotherapy. It may reflect tissue deposition of gold and be of value in predicting clinical improvement or toxic reactions. We studied 21 patients with rheumatoid arthritis on chrysotherapy but could find no relationship between the appearance of ocular chrysiasis, clinical improvement, and toxicity.

Gold salts have been used in rheumatoid arthritis since 1927,1 although their efficacy was not conclusively demonstrated until $1961 .^{2}$ Since 1961 there has been continuous change in the regimens used for chrysotherapy and in the selection of patients. Careful monitoring of therapy has reduced the risk of serious toxicity, and gold tends to be given more frequently and much earlier in the course of the disease. In the days of the $1000 \mathrm{mg}$ course of gold given as $50 \mathrm{mg}$ weekly cutaneous and mucocutaneous toxicity was relatively common after $600 \mathrm{mg}$ had been given. ${ }^{3-5}$ With a higher proportion of 'early' patients being treated with gold, toxicity as a doserelated problem is likely to increase, as 'early' patients seem to require a smaller total dose to induce a remission. ${ }^{5}$

Attempts to predict impending toxicity by measuring gold levels in plasma, skin, hair, and nails have been disappointing, and eosinophilia or raised serum IgE levels are relatively nonspecific. ${ }^{6-8} \mathrm{~A}$ simple noninvasive method of assessing tissue deposition of gold might offer the clinician useful support in deciding the right time to change from weekly injections and in predicting toxicity.

Ocular chrysiasis is a well-recognised phenomenon of gold therapy. Deposition of gold in the cornea has usually been noted after a total dose of $1500 \mathrm{mg}$. It is thought to increase with the total dose and diminish after cessation of gold therapy, and to be of no clinical significance. We have looked at ocular chrysiasis from a different point of view. If ocular chrysiasis is an index of tissue deposition of gold, would its appearance in the cornea coincide with clinical improvement and allow us to use corneal

Accepted for publication 13 January 1981 .

Correspondence to Dr J. M. Gumpel, Northwick Park Hospital, Watford Road, Harrow, Middlesex HA1 3UJ. chrysiasis as an index of the best dose of gold at which to change the frequency of injections? Alternatively would it reflect impending tissue saturation and give warning of cutaneous or mucocutaneous reactions?

\section{Materials and methods}

Twenty-one patients with rheumatoid arthritisundergoing chrysotherapy were examined on one or more occasions by an ophthalmologist. All were receiving sodium aurothiomalate (Myocrisin), the total doses ranging from $562.5 \mathrm{mg}$ to $2050 \mathrm{mg}$. The usual chrysotherapy regime used was a $10 \mathrm{mg}$ test dose, followed by $50 \mathrm{mg}$ weekly until major improvement occurred, then fortnightly with gradual increase in the intervals. In the event of toxicity gold was withdrawn until the side effect cleared, and treatment was reintroduced with a greater interval between injections or with smaller doses. If no improvement occurs, $100 \mathrm{mg}$ injections are given, usually after a total dose of 800-1000 mg have already been given.

Slit-lamp examination was performed without knowledge of the total dose of gold, and the presence or absence of corneal chrysiasis was recorded. An assessment of each patient's disease activity was made at the same visit by an independent observer, not involved in the patient's management. Evidence of clinical improvement and changes in haemoglobin levels and the erythrocyte sedimentation rate (ESR) during gold therapy were determined from the patient and from the case notes. Subjective improvement was assessed by a reduction in the number of symptomatic joints and duration of morning and immobility stiffness. Any possible side effect of gold was sought from the patient and from the outpatient records. 


\section{Results}

Corneal chrysiasis was visualised as numerous tiny yellowish-brown glistening deposits, irregularly placed throughout the cornea. ${ }^{9}$ Of the 21 patients examined $13(62 \%)$ had corneal chrysiasis. Of these 13 patients 11 had received a total dose of less than $1500 \mathrm{mg}$ (Table 1) and 3 had not yet improved. The dosage schedules, duration of treatment, and total doses of gold were comparable in those with and without corneal chrysiasis (Table 1). Of the latter, 7 had improved. In 1 patient who had no corneal chrysiasis at a total dose of $710 \mathrm{mg}$ slit-lamp examination was repeated and corneal chrysiasis found at $860 \mathrm{mg}$.

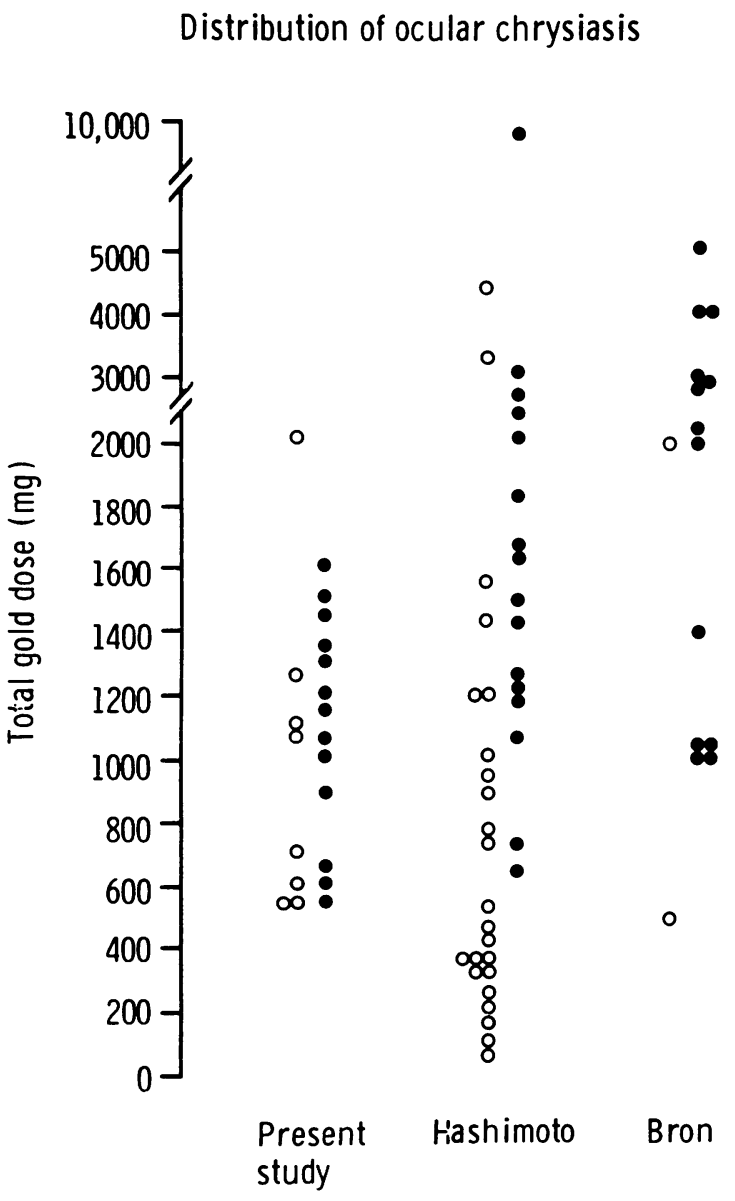

- Ocular chrysiasis present

- Ocular chrysiasis absent

Fig. 1 Presence or absence of ocular chrysiasis $\bigcirc$ according to total gold dosage $(\mathrm{mg})$ in our patients, compared with those of Hashimoto and Bron et al. 11

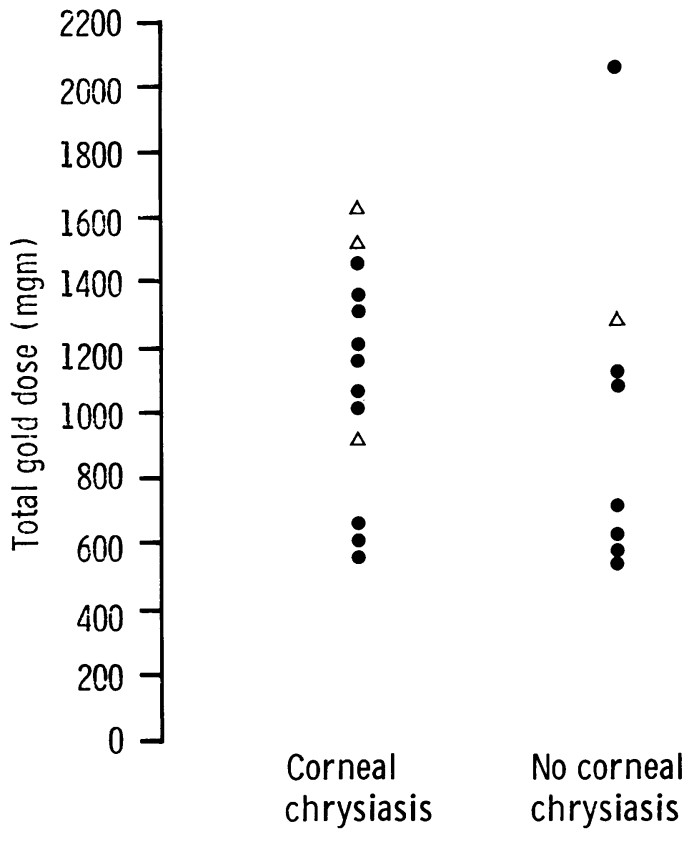

- Clinical improvement

$\triangle$ No clinical improvement

Fig. 2 Response to chrysotherapy (๑ improvement $\triangle$ no improvement) in patients with and without ocular chrysiasis according to total gold dosage.

Seven patients (33\%) had developed reactions possibly attributable to gold therapy - oral ulceration (4), skin rash (1), pruritus (1), and proteinuria (1). Of the 6 patients with mucocutaneous complications 3 had corneal deposits. In the 1 patient who developed proteinuria corneal deposits were also present; he had received $50 \mathrm{mg}$ injections weekly till $960 \mathrm{mg}$, then $100 \mathrm{mg}$ weekly injections till $1160 \mathrm{mg}$, but had ceased therapy 2 months prior to slit-lamp examination. No amyloid deposits were seen on rectal biopsy.

\section{Discussion}

This study explored a possible relationship between corneal chrysiasis and the best total dose of gold at which to alter the injection interval, or the possible onset of toxic symptoms, on the premise that the appearance of corneal chrysiasis reflects tissue gold levels. Our results show that major clinical improvement or toxic symptoms occur independently of corneal chrysiasis. Thus corneal chrysiasis would appear not to be related to the 'best' dose to have predictive value for possible complications of gold therapy (Fig. 1).

Corneal deposition of gold during chrysotherapy 
Table Corneal chrysiasis and clinical data in 21 patients with rheumatoid arthritis.

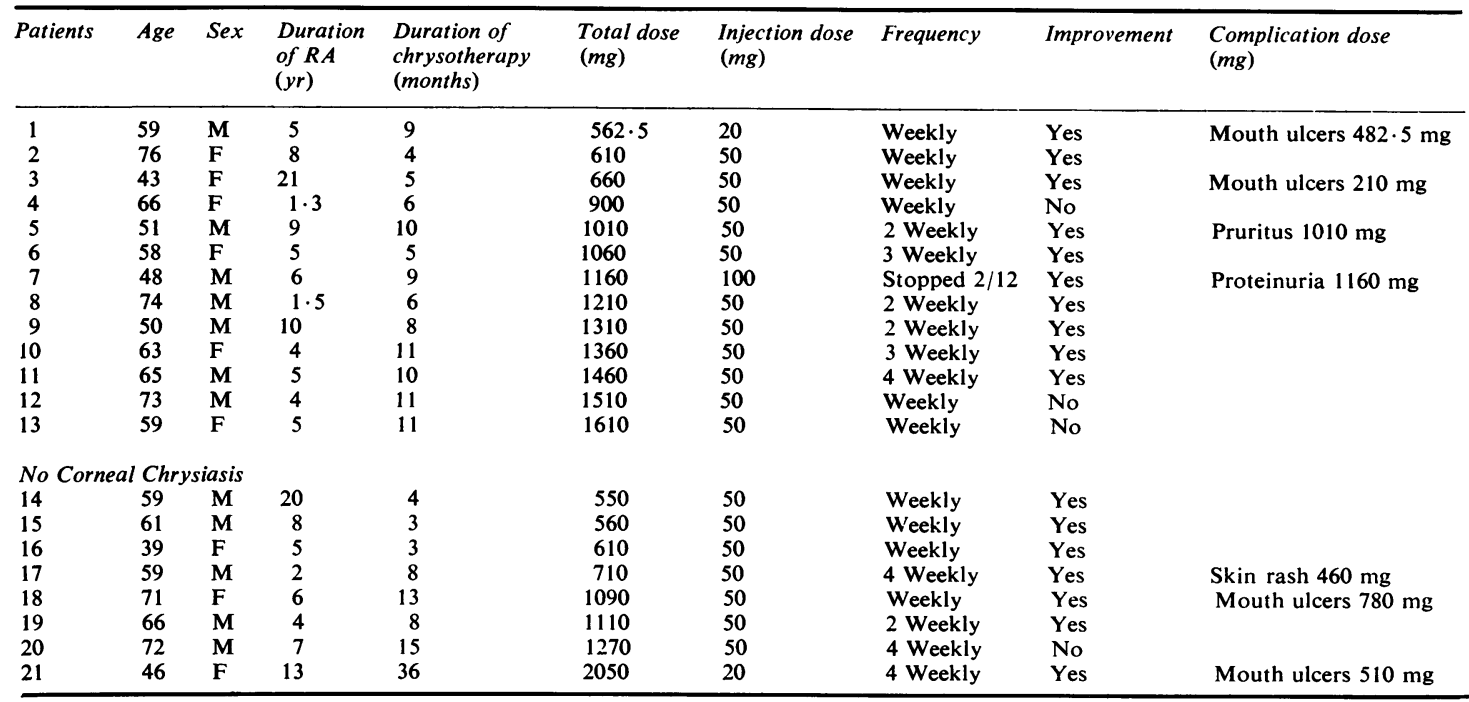

Ocular chrysiasis was noted in patient 16 at dose $860 \mathrm{mg}$.

has been recognised for many years. Roberts and Walter in 1956 described a case in detail, considering it a rare occurrence. ${ }^{10}$ In several series of patients examined for ocular chrysiasis, usually after $1 \mathrm{~g}$ had been givern, corneal gold deposition has been found in percentages varying from $8 \%$ (Dippy) to $87 \%$ (Bron) ${ }^{11-14}$ (and J. Dippy, 1979, personal communication). This difference cannot be explained just by variation in the total dose range of gold among the groups studied, as the range of total gold dosage and distribution within the dose ranges were comparable (Fig. 2) In these studies corneal chrysiasis was found mainly in the group who had received $1500 \mathrm{mg}$ or more total dose. Our interest was in patients who had received smaller total gold doses, between 500 and $1500 \mathrm{mg}$ total dose of gold. Hashimoto suggested in his study that corneal chrysiasis may be related to the individual dose and frequency of gold injections. He found corneal chrysiasis in $47 \%$ of his patients who had received between 500 and $1500 \mathrm{mg}$ total dose, compared with $61 \%$ in our group over the same total dose range. Within the limits of our study group we did not find that the presence of corneal chrysiasis appeared to relate to the size or frequency of the gold injections (Table 1).

\section{References}

1 Lande I K. Die günstige Beeinflussung Schleichender Dauerinfekte durch Solganal. Munch Med Wochenschr 1927; 74: 1132-7.
2 Empire Rheumatism Council. Goldtherapy in rheumatoid arthritis: final report of a multicentre controlled trial. Ann Rheum Dis 1961; 20: 315-33.

${ }^{3}$ Kay A G L. Myelotoxicity of gold. $B r$ Med J 1976; i:قै 1266-8.

4 Huskisson E C, Gibson T J, Balme H W, et al. Trial comparing D-penicillamine and gold in rheumatoid arthritis. Ann Rheum Dis 1974; 33: 532-8.

5 Gumpel J M. Cyclophosphamide, gold and penicillamine - disease modifying drugs in rheumatoid arthritistailored dosage and ultimate success. Rheumatol Rehabil 1976; 15: 217-20.

6 Gottlieb M L, Smith P M, Pennys M S, Smith E M. Gold concentrations in hair, nail and skin during chrysotherapy. Arthritis Rheum 1974; 17: 56-62.

7 Penneys M S, Kramer K, Gottlieb M L. The quantitative distribution of gold in skin during chrysotherapy. $J$ Invest Dermatol 1975; 65: 331-3.

8 Davis P, Hughes G V R. Significance of eosinophilia during gold therapy. Arthritis Rheum 1974; 17: 964-8.

9 Bron A J. Vortex patterns of the corneal epithelium. Trans Opthalmol Soc U K 1973; 93: 455-72.

10 Roberts W, Walter J R. Ocular chrysiasis. Arch Ophthalmol 1956; 56: 48-52.

11 Bron A J, McLendon B F, Camp A V. Epithelial deposition of gold in the cornea in patients receiving systemic therapy. Ain J Opthalmol 1979; 88: 354-60.

12 Hashimoto A, Maeda Y, Ito H, Okazaki M, Hara T. Corneal chrysiasis: a clinical study in rheumatoid arthritis patients receiving gold. Arthritis Rheum 1972; 15: 309-12.

13 Gottlieb M L, Major J C. Ocular chrysiasis correlated with gold concentrations in the crystal line lens during chrysotherapy. Arthritis Rheum 1978; 21 : 704-8.

14 Rodenhauser J H, Behrend T. Art und häufigkeit der Augenbeteiligung nach Parenteraler gold Therapie. Dtsch Med Wochenschr 1969; 94: 2380-92. 